\title{
Az irónia és a hazugság kommunikatív komponenseinek felismerése 5-10 éves korban*
}

\section{Bevezetés}

1.1. Irónia, tudatelmélet és metapragmatikai tudás. A tanulmány az ironikus kijelentések megértésének fejlődését vizsgálja tipikus fejlődésű gyerekek körében. Elsősorban arra a kérdésre keressük a választ, hogy a kognitív tényezők (memória, figyelem stb.) mellett társas-kulturális tényezőknek (társas hagyományok ismerete) is lehet-e szerepe az iróniaértésben. Tanulmányunk a kognitív pszichológia fogalom- és eszközrendszerére támaszkodik, amely idegen lehet a nyelvész olvasó számára. Igyekszünk fogalmainkat egyértelmüen definiálni és következtetéseinket lépésről lépésre megindokolni, de a közös vállalkozás sikerének érdekében olvasóink részéről némi nyitottságot kérünk.

Az iróniát a pragmatikai jelenségek egy speciális fajtájának tekintjük, melynek - nagyon informálisan - fő jellemzöje, hogy a beszélő szándékolt üzenete a mondat szemantikai jelentésének éppen az ellenkezőjére utal, mint az (1) példában.

(1) Jancsi nyakig sárosan megy haza a kirándulásról. Anya azt mondja Apának:

- Nézd, milyen szép tisztán jött haza Jancsi!

Ez ellentétben áll a nyelv hagyományos, kompozicionális modelljének alapvetésével, miszerint egy mondat jelentése és egyben üzenete a szavak és nyelvtani szerkezetek jelentéséből és egy-egy állítás igazságértékeiből tevődik össze. Az irónia (és egyéb pragmatikai jelenségek) esetében ezért megkülönböztethetjük a szemantikai vagy ún. mondat-jelentést a pragmatikai vagy ún. beszélö-jelentéstől (SPERBER-WILSON 1986/1995, WILSON-SPERBER 2004). A pragmatikai jelentés megértésének képessége viszonylag lassan fejlődik gyermekkorban a lexikális és nyelvtani tudáshoz képest, és az iróniaértés még a pragmatikai jelenségeken belül is jelentős elmaradást mutat (pl. BERNICOT et al. 2007; FILIPPOVA-ASTINGTON 2008). Ennek egyik lehetséges magyarázata az, hogy a beszélő szándékolt üzenetének a megértéséhez a nyelvi (lexikális, szintaktikai, diskurzustani) kompetencián túl szükség lehet nem nyelvi kognitív és/vagy társas-kulturális készségekre. A kognitív készségek közül az iróniaértés esetében központi szerepet tulajdoníthatunk a szándéktulajdonítás képességének (HAPPÉ 1993; SULLIVAN 1995), a társas-kulturális ismeretek közül pedig a metapragmatikai tudásnak (BERNICOT et al. 2007).

* Köszönjünk névtelen bírálóinknak, hogy alapos és türelmes munkájuk eredményeként a tudományos paradigmák között tátongó szakadékot tudomásunkra hozták. Sok alapvető fontosságú kérdést felvetettek, amelyek megvitatása azonban túlmutat a tanulmány keretein. A kutatást az NKFI K 115544 sz. pályázata támogatta. Etikai engedély száma: EPKEB 2016/031.

Magyar Nyelv 115. 2019: 164-175. DOI: 10.18349/MagyarNyelv.2019.2.164 
A szándéktulajdonítás képessége a tudatelmélet egyik komponensének tekinthető, azaz azt a képességet feltételezi, hogy az egyén másoknak intencionális tudatállapotot, vágyakat, vélekedéseket képes tulajdonítani. Ez teszi lehetővé, hogy az ironikus kijelentés hallgatója felismerje, hogy a beszélő kommunikációs szándékai eltérnek a kijelentés által kódolt szemantikai jelentéstől. Egy ironikus kijelentés esetében a beszélő intencionális tudatállapotának felismeréséhez három különböző ismeretre van szükség: 1. fel kell mérni a beszélő helyzetismeretét, 2 . ki kell következtetni a beszélö kommunikatív szándékait, és 3. meg kell becsülni a beszélő hozzáállását az adott helyzethez.

A fenti (1) példa esetében ez annyit jelent, hogy a hallgatónak elöször is fel kell ismernie, hogy a beszélö tudja, hogy Jancsi nem tiszta, hiszen csak abban az esetben lehet a kijelentés ironikus. Ez azonban nem elégséges, mert nemcsak az ironizálás jellemzője, hogy olyat állítunk, amit nem hiszünk, hanem a szándékos megtévesztésé is. Az irónia és a szándékos megtévesztés közös tulajdonsága tehát, hogy mindkét esetben az adott tényállást tekintve hamis igazságértékkel bíró, a mondatjelentésükre nézve szó szerint hamis állításokról van szó. A fő különbség a két megnyilatkozás között a beszélő szándékában mutatkozik meg: az irónia esetében a beszélö szándéka felhívni a hallgató figyelmét arra, hogy valamiféle konfliktus áll fenn az állítás és a tényállás között, míg a megtévesztés esetében az a beszélő szándéka, hogy elhitesse a hallgatóval, hogy az állítás igaz. Az irónia helyes értelmezéséhez továbbá fel kell ismerni a beszélőnek az adott megnyilatkozással kapcsolatos attitüdjét, ami lehet humor, kritika, esetleg dicséret stb. az ironizálás esetében, a szándékos megtévesztés esetében viszont ezek egyike sem.

A tudatelméleten túl a másik nem szük értelemben vett nyelvi készség, amely jelentős szerepet játszhat az iróniaértésben, az irónia megértésével kapcsolatos metapragmatikai tudás (BERNICOT et al. 2007). A tanulmányban metapragmatikai tudás alatt egyszerüen annak a felismerését értjük, hogy nem csupán a szó szerint értett nyelv, hanem a nyelvnek a nem szó szerinti értelemben való használata is kulturálisan elfogadott kommunikációs eszköz. Más szóval ahhoz, hogy a hallgató felismerje a beszélő szándékait, elöször is tudnia kell, hogy egy kulturálisan elfogadott, valamiféle többletüzenettel bíró lehetőség az, hogy a beszélö-jelentés eltér a mondat-jelentéstől.

1.2. Az iróniaértés fejlódésének összefüggései a tudatelmélettel és metapragmatikai tudással - empirikus adatok. A tudatelmélet és a metapragmatikai tudás egymáshoz viszonyított szerepe az iróniaértés fejlődésében vita tárgya az irodalomban. Míg az elméleti megfontolásokból egyértelmüen következik, hogy valamiféle tudatelméleti képességre szükség van az iróniértéshez, az empirikus adatok ellentmondásosak. A tudatelmélet mérésére a kutatók tipikusan a másodrendủ hamisvélekedés-teszt valamilyen formáját vagy egy faux pas feladatot (STONE et al. 1998) használnak. A másodrendủ hamisvélekedés-tesztekben egy történet egyik szereplője tévesen gondolja egy másik szereplőről, hogy annak hamis információja van a dolgok állásáról. A teszt azt méri, hogy a kísérleti személy felismeri-e az első szereplő hamis vélekedését. A faux pas feladatok történeteiben egy szereplő kínos helyzetbe kerül (pl. eltéveszti valakinek a nevét, amikor bemutatja egy harmadik személynek), és a helyzet kínosságának felismeréséhez a kísérleti személynek fel kell ismernie a szereplők egymás vélekedéséről való vélekedését. 
Mára klasszikussá vált tanulmányában HAPPÉ (1993) korrelációt talált másodrendủ tudatelméleti képességek és az iróniaértés között tipikus fejlődésű és autista gyerekek körében is. HAPPÉ eredményeit tipikus fejlődésủ gyerekekkel több nyelven is replikálták, magyar mintán SCHNELL (2005) mutatott ki hasonló összefüggéseket. Más kutatók azonban más eredményre jutottak, bár a kísérleti módszerek és a vizsgált populációk is némiképp eltértek. SULLIVAN és munkatársai (1995, továbbá 2003) tipikus fejlődésü és Williams-szindrómás gyerekekkel végzett kutatásaik során azt a következtetést vonták le, hogy a fejlett tudatelméleti képesség nem elégséges feltétele az iróniaértésnek. CUTICA és munkatársai (2006) balagyfélteke-sérült felnőttek között figyeltek meg iróniaértési nehézségeket annak ellenére, hogy a betegek tudatelméleti képessége sértetlen maradt. Korábbi kutatásukban a jelen tanulmány szerzői sem találtak összefüggést a tudatelmélet és az iróniaértés között tipikus fejlődésü gyerekeknél (SZÜCS-BABARCZY 2017). Ezen tanulmányok közös konklúziója, hogy a másodrendủ tudatelmélet lehet szükséges, de semmiképpen sem elégséges feltétele az iróniaértésnek.

A fenti tanulmányok nemcsak a tudatelmélet, hanem az iróniaértés mérésére is egymáshoz hasonló feladatokat használtak: egy történet ironikus kijelentéssel vagy nem verbális gesztussal végződik, és a kísérleti személy feladata a beszélő vagy szereplő szándékainak megállapítása egy szöveges leírás vagy kép kiválasztásával, ahol a választási lehetőségek szó szerinti jelentést, megtévesztést vagy iróniát jelképeznek. A jelen tanulmány szempontjából a módszernek az a jellemzője lényeges, hogy kizárólag a beszélő szándékának felismerését teszteli közvetlen módon. Ennek a jelentőségére az 2. fejezetben visszatérünk.

A metapragmatikai tudás szerepe az iróniaértésben jóval kevesebb figyelmet kapott az irodalomban. BERNICOT és munkatársai (2007) tipikus fejlödésü 6-10 éves gyerekek pragmatikai tudását vizsgálták olyan feladatban, ahol célzásokat, idiómákat és ironikus kijelentéseket kellett képekkel párosítani. A párosítás elvégzése után a gyerekeknek kérdéseket tettek fel arra vonatkozóan, hogy miért az adott képet választották az adott kifejezéshez. A kísérlet eredménye szerint a célzásokra és idiómákra adott helyes képválasztások nem feltétlenül jártak együtt helyes magyarázatokkal, az ironikus kifejezések esetében viszont a helyes képválasztásokat helyes magyarázatok kísérték. A szerzők úgy értelmezték eredményeiket, hogy az iróniára vonatkozó metapragmatikai tudás szerepet játszhat az irónia megértésében, vagyis a helyes (ironikus) interpretáció létrejöttéhez szükség lehet az iróniára vonatkozó metapragmatikai tudásra.

Ez az elméleti lehetőség motiválta korábbi kutatásunkat (SZÜCS-BABARCZY 2017): míg BERNICOT és munkatársai csak együttjárást mutattak ki, mi olyan kísérletet hoztunk létre, mely bizonyíthatja az iróniára vonatkozó metapragmatikai tudás fejlesztésének ok-okozati hatását az irónia megértésében nyújtott teljesítményre nézve óvodáskorú (5-7 éves) gyerekek körében. Vizsgálatunkban egy három alkalomból álló metapragmatikai tréning segítségével explicit ismereteket nyújtottunk az iróniáról mint kommunikációs eszközről és az ironikus intencióra utaló tényezőkről olyan gyerekeknek, akik egy előzetes felmérésünk alapján a véletlen szintjén teljesítettek egy iróniamegértési teszten. Az elvégzett teszt klaszszikus szándékválasztási teszt volt: történetek ironikus kijelentéssel végződtek, és 
a feladat a beszélő szándékának kiválasztása volt három lehetőség közül: szó szerint értette, be akart valakit csapni, vagy viccelődött. Az ironikus szándékot kisgyerekes szülőkkel való egyeztetés eredményeként a „viccelődik” szóval fejeztük ki. A tréning után megismételt iróniateszt eredményei alapján azt találtuk, hogy a tréningen résztvevő gyermekek teljesítménye szignifikáns mértékủ javulást mutatott a feladatban. Ezek az eredmények alátámasztják BERNICOT és munkatársai hipotézisét, miszerint ok-okozati összefüggés van a metapragmatikai tudás és az iróniaértés között. Az eddigiekből tehát az a kép látszik kirajzolódni, hogy az iróniaértés a tudatelméleti képességeken felül a metapragmatikai tudás függvénye is, vagyis nem csupán kognitív, hanem társas-kulturális jelenség is.

\section{Megválaszolatlan kérdések: az irónia és a megtévesztés megkülönböz-}

tetése. SZÜCS-BABARCZY (2017) tréning előtti hibaanalízise azt is megmutatta, hogy a gyerekek leggyakrabban szándékos megtévesztésként értelmezik az ironikus megnyilatkozásokat. Korábban hasonló eredményre jutott WINNER (1997), valamint SULLIVAN et al. $(1995,2003)$ is. Eredményeink felvetik a kérdést, hogy a metapragmatikai tréning valóban az ironikus szándék felismerését segítette-e, vagy inkább arra ösztönözte a gyerekeket, hogy minden szó szerint hamis állítást ironikusnak kategorizáljanak. A kérdés megválaszolására újabb, az előzővel megegyező vizsgálatot végeztünk, azzal a különbséggel, hogy az iróniaértést mérő tesztet kiegészítettük szó szerint igaz állításokkal, valamint megtévesztő szándékú hamis állításokkal. Mindhárom kijelentéstípust (ironikus, szó szerint igaz, megtévesztés) egy szándékra vonatkozó feleletválasztós kérdés követett (szó szerint értette a beszélő, be akart csapni valakit, viccelődött). A teszt irónia-kondíciójában a véletlen szintje alatt teljesító gyerekeket két csoportra osztottuk. A kísérleti csoport részt vett egy metapragmatikai tréningen, ami megegyezett az elöző vizsgálatban alkalmazott tréninggel, majd mindkét csoporttal ismételten felvettük az irónia-megtévesztés tesztet.

Az eredmények arra utalnak, hogy a metapragmatikai tréning bizonyos mértékben segíti az iróniaértést, de nem szünteti meg a bizonytalanságot az ironikus és a megtévesztő szándék megkülönböztetését illetően: az iróniaértés szignifikánsan javult a kísérleti csoportban (átlag 21\%-ról átlag 53\%-ra), a megtévesztés felismerésén nyújtott teljesítmény ezzel szemben szignifikánsan romlott (átlag 62\%-ról átlag 47\%-ra). Felmerül, hogy az a magyarázat az eredményekre, hogy a tréning elött megtévesztésnek vélt állításokat a tréning után ironikusnak kategorizálták a gyerekek. További elemzések azonban kizárják ezt a feltevést: az iróniateljesítmény javulása és a megtévesztésteljesítmény romlása között nem volt korreláció, és a tréninget követő teszt hibaelemzése szerint az irónia- és a megtévesztés-kondícióban adott helytelen válaszok között is jelentős arányban fordult elő a „szó szerint értette” válasz (a hibák 57 és 38\%-a). Az eddigi eredmények tehát arra utalnak, hogy a tréning eredményeként tudatosult a gyerekekben az irónia társas-kulturális funkciója, mint egy kvázi harmadik igazságérték (1. ALBERTI et al. 2014), amelynek a pontos meghatározása azonban bizonytalan maradt. Ezen felül érdemes megjegyezni, hogy a helytelenül adott „szó szerint értette” válaszok felvetik a kérdést, hogy kizárólag a beszélő szándékainak a felismerése okozza-e a problémát, vagy más akadályok is állhatnak az iróniaértés útjában. 
Amint azt az 1.1 alfejezetben tárgyaltuk, egy ironikus kijelentés esetében a beszélő intencionális tudatállapotának felismeréséhez ismerni kell a beszélő helyzetismeretét, majd ki kell következtetni a beszélő kommunikatív szándékait. A fent leírt, a szakirodalomban leggyakrabban használt iróniateszt azonban nem tesz különbséget a két ismeret között, mivel azt a hipotézist vizsgálja, hogy felismerik-e a gyerekek az ironikus szándékot. Mi itt szeretnénk letérni erről az útról, és arra keressük a választ, hogy a szándéktulajdonítási nehézségeken túl lehet-e más, társas-kulturális oka az iróniaértés késői fejlődésének. Konkrétan azt vizsgáljuk egy PEXMAN-GLENWRIGHT (2007) által kifejlesztett iróniateszt adaptálásával, hogy az iróniaértés három komponense (a beszélő helyzetismeretének felismerése, a beszélő szándékának felismerése és a beszélő helyzethez való hozzáállásának a megítélése) hogyan viszonyul egymáshoz különböző életkorokban, azaz az iróniaértés fejlődésének különböző fázisaiban.

\section{A vizsgálat}

\subsection{Módszer}

3.1.1. Vizsgálati személyek. A kísérletben 91 fó, 5-10 éves magyar anyanyelvü, tipikus fejlődésü óvodás és kisiskolás gyermek vett részt, amiért matricát kaptak köszönetképpen. A gyerekeket három csoportra osztottuk az iskolarendszerben elfoglalt helyük szerint: óvodások, első osztályosok és harmadik osztályosok. A csoportokat azért alakítottuk ki iskolai osztály, és nem kor szerint, mert ebben a korosztályban a társas-kulturális ismereteket jellemzően jobban befolyásolja az iskolai környezet, mint az életkori hónapok száma. A gyerekek adatait az 1. táblázat mutatja.

\section{1. táblázat}

A vizsgálati személyek létszám- és életkori adatai

\begin{tabular}{|l|c|c|}
\hline & $\mathrm{N}$ & Átlagos kor (terjedelem): év;hó \\
\hline Óvodás csoport & 30 & $6 ; 0(5 ; 2-6 ; 7)$ \\
\hline Első osztályos csoport & 32 & $7 ; 6(6 ; 0-8 ; 6)$ \\
\hline Harmadik osztályos csoport & 29 & $9 ; 2(8 ; 3-9 ; 10)$ \\
\hline
\end{tabular}

3.1.2. Kísérleti anyagok. A kísérlethez egyetlen tesztet használtunk. A teszt az irónia és a megtévesztés megértését vizsgálja. Öt rövid, egymástól független hétköznapi történetből áll, melyeket képek illusztrálnak. Minden történet három részre oszlik, és minden rész végén a történet egyik szereplője tesz egy kijelentést. Egy történeten belül az egyik kijelentés szó szerint igaz állítás; a másik kijelentés szó szerint hamis, és ironikus szándékkal mondja ki a szereplö; a harmadik pedig szintén szó szerint hamis, de megtévesztési szándékkal mondja ki a szereplö. A szó szerint igaz, ironikus és megtévesztő állítások mindegyikéből tehát összesen öt hangzott el, és sorrendjük randomizálva volt az öt történetben. A történeteket és a három kijelentéstípust a (2-4) példák mutatják be. 
(2) Jancsi a kedvenc zenéjét hallgatja a szobájában. A ruhái szanaszét hevernek a földön. Anyukája bejön, és azt mondja:

(3) - Milyen szép rend van ebben a szobában.

(4) Később Jancsi apukája jön be. Meglátja a saját pólóját a földön, és azt mondja:

- Jancsi, az az én pólóm.

(5) Apuka szeretné visszakapni a pólóját, de Jancsi nem akarja visszaadni, és ezt mondja:

(6) - Megkérdeztem anyát, és azt mondta, megtarthatom.

A 15 állítás mindegyikéhez három kérdés tartozik. Az első a beszélőnek a tényállásról való vélekedésére kérdez rá, a második a beszélő szándékára, a harmadik pedig a beszélőnek a helyzethez való attitüdjére. A vélekedés kérdésre igen/nem válasz volt adható, a szándék kérdésre három, arcokkal kifejezett válaszból lehetett választani (komolyan gondolta, amit mondott; viccelődött; be akarta csapni a hallgatót), az attitüd kérdésre pedig öt, arcokkal kifejezett válaszlehetőség volt (nagyon kedvestől a nagyon undokig). A kérdésekre és válaszlehetôségekre példa a (5-7) alatt található.

(7) Vélekedés: Amikor Anya azt mondta, milyen szép rend van ebben a szobában, azt gondolta, hogy rend van a szobában, vagy hogy nincs rend a szobában?

(8) Szándék: Mutass rá arra az arcra, ami azt mutatja, hogy Anya viccelödött Jancsival, be akarta csapni Jancsit, vagy komolyan gondolta, amikor azt mondta, milyen szép rend van ebben a szobában.
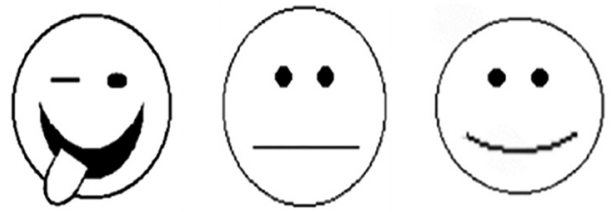

(9) Attitüd: Mutass rá arra az arca, ami azt mutatja, hogy mennyire kedves vagy undok volt Anya, amikor azt mondta, milyen szép rend van ebben a szobában.
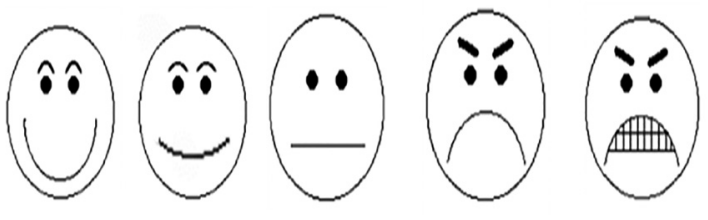

A válaszlehetőségekben használt szavakat és arcrajzokat kisgyerekes felnőtt személyek bevonásával választottuk ki, és az arcrajzok érthetőségét felnőtt kísérleti személyekkel előteszteltük. 
3.1.3. Eljárás. A vizsgálatot a gyerekek megszokott óvodájában, illetve iskolájában egyénileg végeztük. Az eljárás az arcrajzok bemutatásával kezdődött, amikor a gyerekeknek megtanítottuk, hogy az egyes arcokhoz milyen kifejezést (viccelődik, komolyan gondolja, be akar csapni, nagyon kedves, nagyon undok) társítunk. Ezután következett a teszt. A történeteket a kísérletvezető olvasta fel természetes intonációval, miközben a történetet illusztráló képek egy számítógép képernyőjén jelentek meg. Miután elhangzott egy tesztállítás, a kísérletvezető feltette az első kérdést. A kérdés és a válaszgombok ezzel egyidőben megjelentek a képernyőn. A gyerekek szóban válaszoltak a kérdésre, és a kísérletvezető a választ a számítógépen rögzítette. Ezután következett a szándék, majd az attitüd kérdés. Ezek esetében az arcrajzos válaszlehetőségek a képernyőn jelentek meg, és a gyermek mutatással adott választ, amit a kísérletvezető a számítógépen rögzített.

A kísérlet 10-15 percet vett igénybe, és egyetlen ülésben végezte el valamennyi kísérleti személy.

3.2. Eredmények. A három kérdésre adott válaszokat külön-külön modellben elemeztük. Mindhárom elemzéshez kevert statisztikai modellt használtunk, amelyben a gyermek és az item random tényezőkként szerepeltek, a csoport és a kijelentéstípus pedig fix változókként.

A vélekedés kérdésre adott válaszok bináris (helyes/nem helyes) függő változót alkottak. A szó szerint igaz kijelentéstípus esetében az 'igen' választ (azt gondolja, amit mondott) tekintettük helyesnek, az ironikus és megtévesztés kijelentéstípusok esetében pedig a 'nem' választ (nem azt gondolja, amit mondott). A helyes válaszok átlagos arányát kijelentéstípusonként és csoportonként az 1. ábra mutatja.

\section{1. ábra}

A vélekedés kérdésre adott helyes válaszok átlagos aránya

kijelentéstípus és csoport szerint

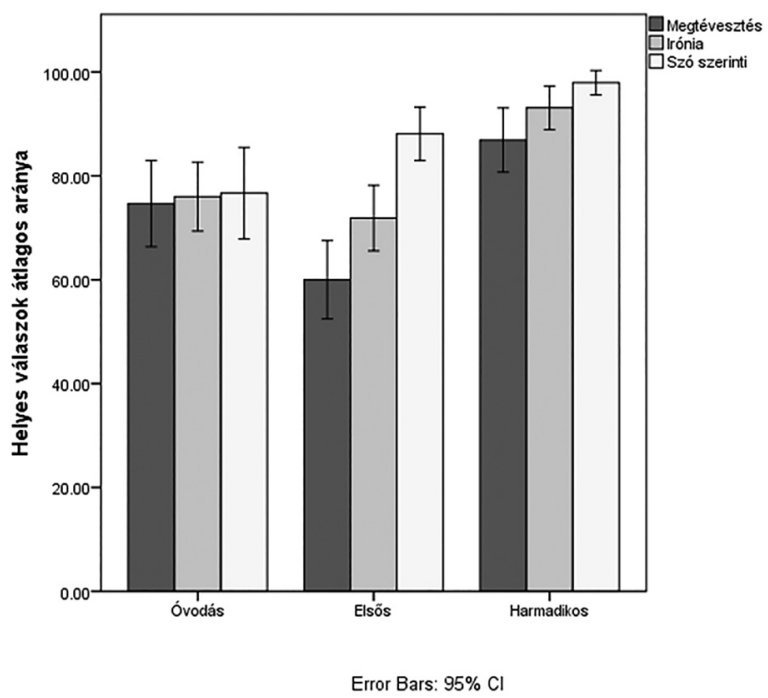


A binomiális logisztikus modell szerint szignifikáns hatása volt a csoportnak $(\mathrm{F}(2 ; 1356)=9,27, \mathrm{p}<, 001)$ : a harmadikosok az óvodásoknál és az elsősöknél is nagyobb eséllyel adtak helyes választ a vélekedés kérdésre, míg a két fiatalabb csoport között nem volt különbség. A kijelentéstípusnak nem volt összhatása, de szignifikáns csoport $\times$ kijelentéstípus interakciót találtunk $(\mathrm{F}(4 ; 1356)=5,59$, $\mathrm{p}<, 001)$, ami annak volt köszönhető, hogy az elsősök jóval kisebb eséllyel ismerték fel a beszélő vélekedését a tényállásról akkor, ha a kijelentés megtévesztő volt, mint akkor, ha a kijelentés szó szerint igaz volt. Más szóval az elsősök gyakran úgy vélték, hogy ha egy beszélö kijelent valamit, a vélekedése minden bizonnyal összhangban van az állítása szemantikai jelentésével. Ez a tendencia rájuk inkább volt jellemző, mint az óvodásokra vagy a harmadikosokra.

A szándék kérdésre adott válaszok szintén bináris (helyes/nem helyes) függő változót alkottak. A szó szerint igaz kijelentéstípus esetében a 'komolyan gondolta' választ tekintettük helyesnek, az ironikus kijelentéstípus esetében a 'viccelődött' választ, a megtévesztés kijelentéstípus esetében pedig a 'be akarta csapni' választ. A helyes válaszok átlagos arányát kijelentéstípusonként és csoportonként a 2. ábra mutatja.

\section{2. ábra}

A szándék kérdésre adott helyes válaszok átlagos aránya kijelentéstípus és csoport szerint

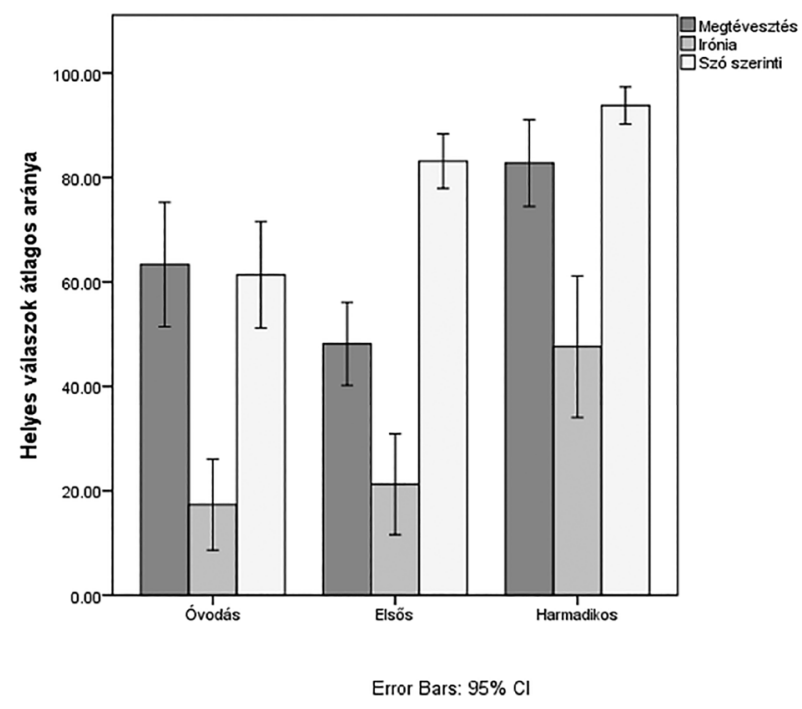

A szándék kérdést elemző binomiális logisztikus modell szerint szignifikáns hatása volt a csoportnak is $(\mathrm{F}(2 ; 1356)=10,71, \mathrm{p}<, 001)$ és a kijelentéstípusnak is $(\mathrm{F}(2 ; 1356)=33,98, \mathrm{p}<, 001)$. A csoport hatása annak köszönhető, hogy az elsősök és a harmadikosok is összességében szignifikánsan nagyobb eséllyel adtak jó választ a szándék kérdésre, mint az óvodások. A kijelentéstípus hatását az okozta, hogy az irónia esetében csoporttól függetlenül szignifikánsan nehe- 
zebb volt megítélni a szándékot, mint a másik két kijelentéstípus esetében. A két változó interakciója nem volt szignifikáns, tehát az iróniához társuló szándék megállapítása minden korban nehéznek bizonyult a másik két kijelentéstípushoz társuló szándék megítéléséhez képest. Ez az eredmény összhangban van az iróniakutatás eddigi eredményeivel.

Az attitüd kérdésre adott válaszok elemzéséhez a válaszokhoz pontértékeket rendeltünk, és az elemzést lineáris kevert modellben végeztük. Mindhárom kijelentéstípus esetében 1-től (nagyon undok) 5-ig (nagyon kedves) terjedő skálán pontoztuk a válaszokat. A válaszok átlagos pontszámát kijelentéstípusonként és csoportonként a 3. ábra mutatja (magasabb pontszám = kedvesebbnek ítélt beszélö).

\section{3. ábra}

Az attitűd kérdésre adott válaszok átlagos pontszáma kijelentéstípus és csoport szerint

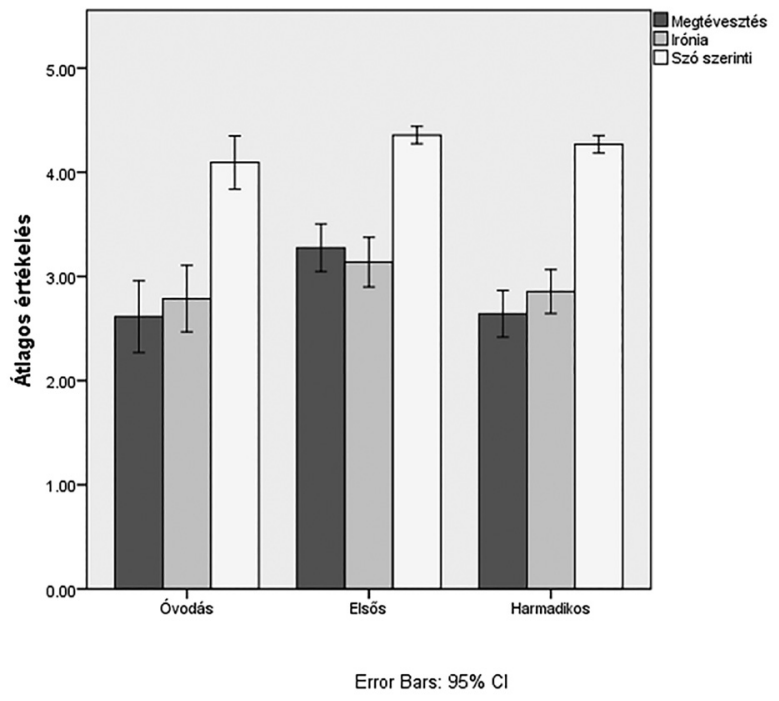

A beszélő attitüdjének megítélésére szignifikáns hatással volt a kijelentéstípus $(\mathrm{F}(2 ; 1356)=7,10, \mathrm{p}=, 001)$ : a gyerekek kedvesebbnek ítélték a szó szerint igaz állítások kimondóját, mint az ironikus vagy a megtévesztő állításokét. Ez a hatás csoporttól függetlenül érvényesült. Ennél érdekesebb eredmény, hogy szignifikáns interakciót figyeltünk meg a két változó között $(\mathrm{F}(4 ; 1356)=5,54$, $\mathrm{p}=, 001)$, ami annak köszönhetö, hogy az elsősök kedvesebbnek ítélték a megtévesztéshez kapcsolódó attitüdöt, mint a másik két csoport.

Érdemes külön megjegyezni, hogy a 3. ábrán összefoglalt adatok nem azt mutatják, hogy a gyerekek milyen attitüdöt rendelnek különböző kommunikatív szándékokhoz, hanem azt, hogy az attitüdök tekintetében érzékenyek-e a három kijelentéstípus közötti különbségre. A kettő azért nem ugyanaz, mert amint azt az előzőekben láttuk, a gyerekek viszonylag nagy eséllyel értik félre a szándékot. 
4. Összefoglalás és konklúziók. A kísérlet főbb eredményei azt mutatják, hogy a két fiatalabb csoport számára nemcsak a beszélő szándékainak, hanem a beszélő vélekedésének a felismerése is nehézséget jelentett. Az elsősök számára a legkisebbeknél is nehezebb volt elfogadni, hogy egy beszélő kijelentése nem feltétlenül egyezik meg a beszélő vélekedésével. Erre nemcsak a megtévesztés kondícióban adott helytelen vélekedésválaszok magas aránya utal, hanem az is, hogy az elsősök a megtévesztő állítások beszélőit kedvesebbnek ítélték, mint a másik két csoport.

Véleményünk szerint, ha az iróniértés problémája csupán kognitív eredetü lenne, a vélekedéskérdésekre a legkisebb gyerekek is könnyedén válaszolnának, és csak a szándék- és attitüdkérdések okoznának nehézséget. Három érv szól amellett, hogy kognitív szempontból a vélekedéskérdés nem okozhat problémát: 1. csupán elsőrendủ tudatelmélet (annak felismerése, hogy különböző egyéneknek különböző tudatállapotai lehetnek) szükséges hozzá, ami már 5 éves tipikus fejlődésű gyerekeknél is többnyire adott; 2 . a történetek megértését illusztrációk segítették, melyek a dolgok valódi állását ábrázolták; és 3. a beszélő vélekedése minden történetben megegyezett a kísérleti személy vélekedésével.

Ha ezzel szemben a probléma társas-kulturális eredetü, a vélekedéskérdés is problémát jelenthet, ha a) a gyerekek nem tulajdonítanak ironikus szándékot a beszélőnek vagy azért, mert nem tudják megkülönböztetni az iróniát a megtévesztéstől, vagy pedig azért, mert nem ismerik az irónia kommunikatív funkcióját; és b) megtévesztési szándékot nem akarnak tulajdonítani egy szereplőnek, mert a megtévesztés kulturálisan nem elfogadott. Ebben az esetben a konfliktust azzal lehet feloldani, ha az egyén feltételezi, hogy a beszélő vélekedése bizonyára eltér az első ránézésre valószínű vélekedéstől, és megegyezik az állítása szemantikai jelentésével.

A mi értelmezésünk szerint tehát ezek az eredmények azt a hipotézist erősítik meg, miszerint az iróniaértés a tudatelméleti képesség mellett társas-kulturális tanulás és tapasztalat kérdése is. Hangsúlyoznunk kell, hogy nem állítjuk, hogy az iróniaértés kizárólag társas-kulturális tanulás és tapasztalat kérdése, hiszen az nem magyarázná a pragmatikai deficitek jelenlétét szerzett zavarok esetén, sem pedig a fejlesztési kísérletek nehézkességét ép intelligenciájú autista populációk esetén. Amit viszont megmagyarázhat a megállapításunk, miszerint az iróniértés részben társas-kulturális jelenség, az az iróniaértés lassú fejlődése még más pragmatikai készségekhez képest is tipikus fejlődésü gyerekek esetében.

Kulcsszók: pragmatikai fejlődés, iróniaértés, metapragmatikai tudás, beszélői szándék.

\section{Hivatkozott irodalom}

ALBERTI, GÁBOR - VADÁSZ, NOÉMI - KLEIBER, JUDIT 2014. Ideal and deviant interlocutors in a formal interpretation system. In: ZUCZKOWSKI, ANDRZEJ - BONGELLI, RAMONA - Riccioni, Ilaria - CANESTRARI, CARLA eds., Communicating Certainty and Uncertainty in Medical, Supportive and Scientific Contexts. John Benjamins, Amsterdam-Philadelphia. 59-78. 
Bernicot, Josie - LaVAl, Virginie - Chaminaud, Stéphanie 2007. Nonliteral language forms in children: In what order are they acquired in pragmatics and metapragmatics? Journal of Pragmatics 39: 2115-2132. https://doi.org/10.1016/j. pragma.2007.05.009

Cutica, Ilaria - Bucciarelli, Monica - BAra, Bruno G. 2006. Neuropragmatics: Extralinguistic pragmatic ability is better preserved in left-hemisphere-damaged patients than in right-hemisphere-damaged patients. Brain and language 98: 12-25. https://doi.org/10.1016/j.bandl.2006.01.001

FilipPova, EVA - Astington, JANET WiLdE W. 2008. Further development in social reasoning revealed in discourse irony understanding. Child Development 79: 126-138. https://doi.org/10.1111/j.1467-8624.2007.01115.x

Happé, Francesca G. E. 1993. Communicative competence and theory of mind in autism: a test of relevance theory. Cognition 48: 101-119. https://doi.org/10.1016/ 0010-0277(93)90026-R

Pexman, Penny M. - Glenwright, Melanie 2007. How do typically developing children grasp the meaning of verbal irony? Journal of Neurolinguistics 20: 178-196. https://doi.org/10.1016/j.jneuroling.2006.06.001

SCHNELL ZSUZSANNA. 2005. Tudatelmélet és pragmatika. In: GERVAIN JUDIT - KovÁcS KRISTÓF - LUKÁCS ÁGNES - RACSMÁNY MIHÁLY szerk., Az ezerarcú elme. Tanulmányok Pléh Csaba 60. születésnapjára. Akadémiai Kiadó, Budapest. 102-116.

SPERBER, DAN - WILSON, DEIRDRE 1986/1995. Relevance: communication and cognition. Harvard University Press, Cambridge (MA.).

Stone, VAlerie E. - Baron-Cohen, Simon - Knight, Robert T. 1998. Frontal lobe contributions to theory of mind. Journal of Cognitive Neuroscience 10: 640-656. https://doi.org/10.1162/089892998562942

Sullivan, Kate - Winner, Ellen - Hopfield, Natalie 1995. How children tell a lie from a joke: The role of second-order mental state attributions. British Journal of Developmental Psychology 13: 191-204. https://doi.org/10.1111/j.2044-835X.1995. tb00673.x

Sullivan, Kate - Winner, Ellen - Tager-Flusberg, Helen 2003. Can adolescents With Williams Syndrome Tell the Difference Between Lies and Jokes? Developmental Neuropsychology 23: 85-103. https://doi.org/10.1080/87565641.2003.9651888

SZÜCS, MÁRTA - BABARCZY, ANNA 2017. The role of metapragmatic awareness in the development of irony comprehension, In: Assimakopoulos, Stavros ed., Pragmatics at its Interfaces, Mouton Series in Pragmatics 17. De Gruyter Mouton, Berlin. $129-148$.

Wilson, DEIRDRE - SPERBER, DAN 2004. Relevance theory. In: HoRN, LAURENCE R. Ward, Gregory ed., The Handbook of Pragmatics. Blackwell Publishing, Malden-Oxford. 607-633.

WINNER, ELLEN 1997. The point of words. Children's Understanding of Metaphor and Irony. Harvard University Press, Cambridge. 


\section{The recognition of communicative components of irony and lying in ages 5 to 10}

In this paper, we investigate the recognition and assessment of speakers' opinions, intentions, and attitudes with respect to utterances involving irony, lies, and literally true statements with 5 to 10 -year-old children (nursery, first-form and third-form primary school children). The participants had to answer an opinion question, an intention question, and an attitude question in a multiple choice comprehension task based on a narrative. Their assessments were investigated in a binary (true/false) scale. While for nursery kids all three types of statements proved to be equally difficult, for third-formers they proved to be equally easy. Unexpectedly, first-formers were the least successful in recognizing lies as lies. There were three possible answers concerning the speaker's intention: the speaker was kidding, he tried to put the listener off, or he meant what he had said. What the respondents found the most difficult was the recognition of the intention behind ironical satements: twe two younger groups performed at chance level, and even the oldest participants assessed the intention correctly in half of the cases only. The intention of misleading was somewhat easier to recognize for all three groups, and the literally true sentences proved to be the easiest to understand. The speaker's attitude was measured against a five-point scale (from 'nasty' to 'nice'). Irony and lying were not differentiated by any of the three groups, and all three groups assessed such speakers significantly nastier than those of literally true statements, although with ten-year-olds that difference was somewhat smaller than with the younger groups.

Keywords: pragmatic development, irony comprehension, metapragmatic awareness, speaker intention.

BABARCZY ANNA

Budapesti Müszaki és Gazdaságtudományi Egyetem

MTA Nyelvtudományi Intézet

SZÜCS MÁRTA ZITA

Szegedi Tudományegyetem 